\title{
Pengaruh Pemberian Insentif, Peningkatan Disiplin, dan Pemberian Motivasi terhadap Hasil Belajar Mahasiswa Politeknik Ganesha Medan
}

\author{
Irma Hariyanti Siregar \\ Politeknik Ganesha Medan \\ irmapolgan@gmail.com

\section{Yus Epi} \\ Politeknik Ganesha Medan \\ yusepi20november@gmail.com
}

\begin{abstract}
Abstrak
Politeknik Ganesha Medan adalah salah satu PTS Program Diploma di Sumatera Utara yang memiliki Visi menjadi Institusi Vokasi terbaik di Indonesia melalui salah satu misinya dengan melakukan pembinaan intelektual untuk menghasilkan alumni yang siap kerja. Berdasarkan hasil observasi awal yang dilakukan terhadap hasil belajar mahasiswa kelas reguler dan kelas karyawan terdapat kesenjangan nilai yang cukup jauh. Penelitian ini bertujuan untuk mengetahui apakah variabel pemberian insentif, peningkatan displin dan pemberian motivasi kepada mahasiswa dapat meningkatkan hasil belajar mahasiswa Polieknik Ganesha Medan. Metode pengambilan sampel menggunakan metode random sampling sebanyak 76 mahasiswa Politeknik Ganesha Medan. Data yang diperoleh akan diuji dengan uji validitas, reliabilitas, normalitas, multikolinearitas dan heterokedastisitas. Teknik analisis data untuk menganalisis hipotesis dalam penelitian ini adalah analisis regresi berganda (Multiple Regression Analysis) untuk menguji variabel bebas (pemberian insentif, peningkatan disiplin dan pemberian motivasi) terhadap variabel terikat (hasil belajar mahasiswa), Uji $\mathrm{F}$ (simultan) dan Uji t (parsial). Hasil analisis regresi dari ketiga variabel independen yang dimasukkan kedalam model regresi (pemberian insentif, peningkatan disiplin, dan pemberian motivasi) bahwa pemberian insentif secara langsung berpengaruh positif dan signifikan terhadap hasil belajar. Peningkatan disiplin secara langsung berpengaruh positif tetapi tidak signifikan terhadap hasil belajar. Pemberian motivasi secara langsung berpengaruh positif dan signifikan terhadap hasil belajar. Pemberian insentif, peningkatan disiplin dan pemberian motivasi secara simultan berpengaruh positif dan signifikan terhadap hasil belajar. Peningkatan disiplin secara langsung berpengaruh positif tetapi tidak signifikan terhadap hasil belajar maka sangat dibutuhkan toleransi untuk mahasiswa kelas karyawan. Besarnya pengaruh variabel pemberian insentif, peningkatan disiplin, motivasi terhadap hasil belajar adalah sebesar 37,9 \% dan sisanya sebesar 62,1\% dipengaruhi oleh faktor atau variabel lain yang tidak diteliti dalam model penelitian ini yang bisa menjadi bahan penelitian selanjutnya.
\end{abstract}

Kata Kunci insentif, disiplin, motivasi, hasil belajar 


\section{PENDAhuluan}

Politeknik Ganesha Medan merupakan salah satu Perguruan Tinggi Swasta Program Diploma di Sumatera Utara yang memiliki Visi menjadi Institusi Vokasi terbaik di Indonesia melalui salah satu misinya dengan melakukan pembinaan intelektual untuk menghasilkan alumni yang siap kerja. Untuk mencapai Visi dan Misi tersebut harus dilakukan berbagai upaya khususnya dalam meningkatkan hasil belajar mahasiswa melalui pemberian insentif, peningkatan disipilin dan motivasi terhadap mahasiswa. Polteknik Ganesha Medan membuka kelas karyawan yang dikhususkan bagi mahasiswa yang bekerja. Berdasarkan hasil observasi awal yang dilakukan terhadap hasil belajar mahasiswa kelas reguler dan kelas karyawan terdapat kesenjangan nilai yang cukup jauh. Hal ini disebabkan karena mahasiswa kelas karyawan lebih sering tidak hadir di kelas saat belajar dan motivasi belajar yang rendah. Aktifitas pekerjaan di luar kampus berpengaruh terhadap hasil belajar mahasiswa dimana kelelahan dan kejenuhan dapat menyebabkan hasil belajar menjadi rendah. Permasalahan ini harus dicari solusinya untuk meningkatkan hasil belajar mahasiswa agar Visi dan Misi Institusi dapat tercapai. Berdasarkan latar belakang masalah yang telah diuraikan diatas, perumusan masalah adalah apakah solusi untuk meningkatkan hasil belajar mahasiswa dapat melalui pemberian insentif, peningkatan disiplin dan pemberian motivasi kepada mahasiswa? Penelitian dibatasi pada Objek penelitian yaitu mahasiswa Politeknik Ganesha Medan baik kelas karyawan maupun kelas reguler.

Adapun kontribusi dari penelitian ini adalah memberikan masukan bagi perguruan tinggi lain tentang bagaimana strategi dalam meningkatkan hasil belajar mahasiswa. Tujuan Penelitian memberikan insentif, peningkatan disiplin dan pemberian motivasi kepada mahasiswa Politeknik Ganesha Medan untuk meningkatkan hasil belajar dan manfaat Penelitian adalah 1) Membantu mahasiswa Politeknik Ganesha Medan 2) Membantu Institusi mengurangi angka DO mahasiswa akibat pandemic Covid-19 dan 3) Membantu dalam pencapaian Visi Perguruan Tinggi untuk menjadi Institusi terbaik di Indonesia. Hasil belajar yang rendah akan membuat Perguruan Tinggi sulit mencapai Visi Misinya. Selain itu dapat menyebabkan mahasiswa menjadi Drop Out. Drop Out bukan hanya akan menyebabkan Perguruan tinggi tidak dapat mencapai Visi Misinya tetapi juga akan mengganggu berjalannya operasional kampus.

\section{LANDASAN TEORI}

\subsection{Insentif}

Insentif dalam penelitian ini merupakan penghargaan yang diberikan oleh pergguruan tinggi kepada mahasiswa yang memliki hasil belajar yang baik. Insentif dimaksudkan untuk dapat meningkatkan hasil belajar dan mempertahankan hasil belajar mahasiswa. Menurut Hariandja (Hariandja, 2012), Insentif merupakan salah satu jenis pengahargaan yang dikaitkan dengan prestasi belajar. Semakin tinggi prestasi belajar semakin besar pula insentif yang diterima. Menurut Hariandja (Hariandja, 2012), Insentif digunakan untuk mendorong siswa dalam memperbaiki kualitas dan kuantitas hasil belajarnya. Pemberian insentif tersebut bermanfaat bagi siswa. Jika insentif yang diterima tidak dikaitkan dengan prestasi belajar, tetapi bersifat pribadi, maka mereka akan merasa adanya ketidakadilan yang dapat mengakibatkan ketidakpuasan yang pada gilirannya dapat mempengaruhi perilaku, misalnya ketidakhadiran dan penurunan prestasi belajar.

Ada tiga jenis insentif menurut Gaol (Gaol, 2014), yaitu financial incentive, non-financial incentive, dan social incentive. Financial incentive berupa pemberian beasiswa, non- 
financial incentive berupa pemberian hiburan pujian, social incentive lebih kepada keadaan dan sikap dari sesama mahasiswa. Financial Incentif dapat mempengaruhi hasil belajar mahasiswa (F Nadiroh) (Nadiroh \& Wahjoedi, 2016)

\subsection{Disiplin}

Berbagai aturan yang disusun oleh Perguruan Tinggi adalah tuntunan untuk mencapai tujuan visi yang telah ditetapkan. Tindakan pendisiplinan dapat merupakan kekuatan positif bagi Perguruan Tinggi apabila ditetapkan secara konsisten dan berkeadilan. Disiplin adalah setiap perorangan dan juga kelompok yang menjamin adanya kepatuhan terhadap perintah dan berinisiatif untuk melakukan suatu tindakan yang diperlukan seandainya tidak ada perintah. (Ranupandojo \& Husnan, 2000) Dalam Penelitiannya Singgih Tego Saputro dan Pardiman mengatakan bahwa disiplin belajar mempengaruhi hasil belajar: (S.T \& P, 2012)

\section{3. Motivasi}

Mahasiswa harus diberi motivasi untuk menggerakkan mahasiswa agar dapat mencapai Visi Perguruan Tinggi.. Pemberian motivasi kepada mahasiswa harus dilakukan secara terus menerus dalam setiap kesempatan baik oleh dosen maupun tenaga kependidikan. Kegiatan extra curikuler seperti seminar motivasi juga perlu dilakuan untuk lebih memperkuat motivasi. Motivasi menentukan perilaku mahasiswa, perilaku merupakan cerminan yang paling sederhana dari motivasi. Menurut (Mangkunegara, 2012) berpendapat bahwa motivasi merupakan proses yang berperan pada intensitas, arah, dan lamanya berlangsung upaya individu kearah pencapaian sasaran (Zuhro, 2016) dalam penelitiannya mengatakan bahwa terdapat pengaruh antara motivasi dengan hadil belajar mahasiswa : (Kingsley, 1999)

\subsection{Hasil Belajar}

Menurut Howard Kingsley, hasil belajar dibedakan dalam 3 kelompok, yaitu (1) keterampilan dan kebiasaan; (2) pengetahuan dan pengertian serta (3) sikap dan cita-cita : (Kingsley, 1999)

Menurut Sardiman, hasil belajar adalah hasil langsung berupa tingkah laku siswa setelah melalui proses belajar-mengajar yang sesuai dengan materi yang dipelajarinya. Sehingga hasil belajar dapat ditafsirkan sebagai output dari proses belajar-mengajar : (Slameto)

Menurut Slameto, output tersebut dipengaruhi oleh faktor jasmaniah, psikologis dan kelelahan yang dikelompokkan sebagai faktor intern. Sedangkan kelompok faktor ekstern- nya meliputi faktor keluarga, sekolah dan masyarakat : (Slameto)

\subsection{Hipotesis}

Hipotesis pada penelitian ini adalah sebagai berikut:

1. Pemberian insentif berpengaruh signifikan terhadap hasil belajar.

2. Peningkatan disiplin berpengaruh signifikan terhadap hasil belajar .

3. Pemberian motivasi berpengaruh signifikan terhadap hasil belajar

4. Pemberian insentif, peningkatan disiplin, dan motivasi berpengaruh signifikan terhadap hasil belajar

\section{METODOLOGI PENELITIAN}

Tahapan yang dilakukan dalam penelitian adalah sebagai berikut :

1. Pengumpulan Data 
Teknik pengumpulan data yang dipergunakan untuk mendapatkan data yang diperlukan adalah dengan wawancara (interview) dilakukan langsung kepada mahasiswa, memberikan daftar pertanyaan (kuisioner) langsung kepada mahasiswa dan studi dokumentasi yang dilakukan dengan mengumpulkan dan mempelajari data yang diperoleh dari bagian akademik. Jenis dan sumber data yang digunakan dalam penelitian ini adalah data primer : diperoleh dari wawancara (interview) dan daftar pertanyaan (kuisioner) dan data skunder yang diperoleh dari studi dokumentasi.

Variabel terikat (dependent) dalam penelitan ini adalah hasil belajar Y, dan variabel bebas (independent variabel) adalah pemberian insentif (X1), peningkatan disiplin (X2), dan pemberian motvasi (X3).

\section{Pengujian Data}

Sebelum kuisioner diberikan kepada responden yang dijadikan sampel penelitian, maka terlebih dahulu harus diuji validitas dan reliabilitas dilakukan pada sampel yang dijadikan responden dalam penelitian.

Uji Validitas digunakan untuk mengukur sah, atau valid tidaknya suatu kuesioner.

Uji Reliabilitas menyatakan/menunjukkan sejauh mana instrumen yang digunakan dalam penelitian dapat dipercaya sebagai alat pengumpulan data dan mampu mengungkap informasi yang sebenarnya dilapangan. Pengujian reliabilitas instrumen dilakuakn dengan menggunakan IBM SPSS Statistics 21.

Uji Normalitas dilakukan untuk melihat apakah nilai risidual terdistribusi secara normal atau tidak. Model regresi yang baik adalah yang memiliki nilai residual yang brdistribusi normal. Uji normalitas Kolmogorov Smirnov merupakan bagian dari uji asumsi klasik. Uji Multikolinearitas yang bertujuan untuk menguji apakah dalam model regresi ditemukan adanya korelasi antar variabel bebas.

Uji Heterokedastisitas yang digunakan untuk menguji apakah dalam model regresi terdapat ketidaksamaan varians dari residual satu pengamatan ke pengamatan yang lain. Salah satu asumsi dalam regresi yang harus dipenuhi adalah bahwa varians dari residual dari satu pengamatan ke pengamatan yang lain tidak memiliki pola tertentu

\section{Teknik Analisis Data}

Alat uji statistik yang dipergunakan untuk menganalisis hipotesis dalam penelitian ini adalah analisis regresi berganda (Multiple Ragression Analysis) untuk menguji variabel bebas (pemberian insentif, peningkatan disiplin dan pemberian motivasi) terhadap variabel terikat (hasil belajar). Analisis regresi linier beganda dipergunakan dalam penelitian ini karena variabel terikat yang dicari dipengaruhi oleh lebih dari satu variabel bebas atau variabel penjelas.

\section{Uji F (Uji secara Simultan)}

Uji F dilakukan untuk melihat secara simultan (bersama-sama) apakah ada pengaruh dari variabel bebas (pemberian insentif, peningkatan disiplin dan pemberian motivasi) terhadap variabel terikat (hasil belajar)

\section{Uji t (Uji Secara Parsial)}

Uji t bertujuan untuk melihat secara parsial apakah ada pengaruh dari variabel bebas yaitu pemberian insentif, peningkatan disiplin dan pemberian motivasi terhadap variabel terikat yaitu hasil belajar mahasiswa Politeknik Ganesha Medan. 
Penelitian ini dilakukan mulai Januari sampai Desember 2021 di Politeknik Ganesha Medan, yang beralamat di J1. Veteran No. 194 Desa Manunggal Kecamatan Labuhan Deli Kabupaten Deli Serdang Sumatera Utara.

\section{Parameter Pengamatan}

Penelitian ini merupakan suatu solusi untuk meningkatkan hasil belajar mahasiswa di perguruan tinggi yang hasilnya dapat digunakan untuk pengamblan kebijakan dan langkah langkah yang tepat sehubungan dengan variable-variable bebas yang diteliti

7. Rancangan Penelitian dan Analisis Data

Metode pengambilan sampel dalam penelitian ini menggunakan random sampling. Kuisioner akan diberikan kepada sampel yang terpilih selanjutnya akan dilakukan pengujian (uji validitas, reliabilitas, normalitas, multikolinearitas, heterokedastisitas). Selanjutnya dilakukan analisis data dengan Uji F dan uji t.

\section{HASIL PENELITIAN}

\section{V.1. Uji Validitas dan Reliabilitas}

\section{A. Uji Validitas}

Uji validitas dilakukan untuk mengetahui valid atau tidaknya angket untuk dijadikan sebagai instrument dalam penelitian. Pada uji coba alat ukur ini menggunakan sejumlah 76 responden, yang terdiri dari variabel bebas (dependent) yaitu pemberian insentif $\left(\mathrm{X}_{1}\right)$, peningkatan disiplin $\left(\mathrm{X}_{2}\right)$, pemberian motivasi $\left(\mathrm{X}_{3}\right)$, dan variabel terikat (independent) yaitu variabel hasil belajar (Y). Angka korelasi (r) hitung yang diperoleh kemudian dibandingkan dengan angka korelasi (r) yang terdapat pada tabel dengan tingkat kesalahan $5 \%$ dan jumlah $\mathrm{n}=76$ dimana diperoleh $\mathrm{r}$ tabel $=0.2227$. Dasar pengambilan keputusan uji validitas adalah :

- $\quad$ Jika nilai $r$ hitung $>r$ tabel maka angket dinyatakan valid

- Jika nilai $r$ hitung < r tabel maka angket dinyatakan valid

Adapun ringkasan hasil uji validitas adalah sebagai berikut.

Hasil Pengujian Validitas Instrumen Variabel Insentif $\left(X_{1}\right)$ SPSS

\begin{tabular}{|c|c|c|c|}
\hline No item & r hitung & r table (5\% 76) & Keterangan \\
\hline 1 & 0,452 & 0,2227 & Valid \\
\hline 2 & 0,331 & 0,2227 & Valid \\
\hline 3 & 0,874 & 0,2227 & Valid \\
\hline 4 & 0,861 & 0,2227 & Valid \\
\hline 5 & 0,884 & 0,2227 & Valid \\
\hline 6 & 0,900 & 0,2227 & Valid \\
\hline
\end{tabular}

Berdasarkan uji validitas instrumen dapat dilihat bahwa $r$ hitung untuk semua item insentif lebih besar dari $r$ table $(0,2227)$. Dapat diambil keputusan bahwwa angket insentif valid

Hasil Pengujian Validitas Instrumen Variabel Disiplin $\left(\mathbf{X}_{2}\right)$ SPSS

\begin{tabular}{|c|c|c|c|}
\hline No item & r hitung & r table (5\% 76) & Keterangan \\
\hline 1 & 0,513 & 0,2227 & Valid \\
\hline 2 & 0,663 & 0,2227 & Valid \\
\hline
\end{tabular}




\begin{tabular}{|c|c|c|c|}
\hline 3 & 0,452 & 0,2227 & Valid \\
\hline 4 & 0,711 & 0,2227 & Valid \\
\hline 5 & 0,627 & 0,2227 & Valid \\
\hline 6 & 0,665 & 0,2227 & Valid \\
\hline 7 & 0,636 & 0,2227 & Valid \\
\hline 8 & 0,687 & 0,2227 & Valid \\
\hline 9 & 0,737 & 0,2227 & Valid \\
\hline 10 & 0,706 & 0,2227 & Valid \\
\hline
\end{tabular}

Berdasarkan uji validitas instrumen dapat dilihat bahwa $r$ hitung untuk semua item disiplin lebih besar dari $r$ table $(0,2227)$. Dapat diambil keputusan bahwwa amgket disipln valid

\section{Hasil Pengujian Validitas Instrumen Variabel Motivasi $\left(X_{3}\right)$ SPSS}

\begin{tabular}{|c|c|c|c|}
\hline No item & r hitung & r table (5\% 76) & Keterangan \\
\hline 1 & 0,552 & 0,2227 & Valid \\
\hline 2 & 0,718 & 0,2227 & Valid \\
\hline 3 & 0,796 & 0,2227 & Valid \\
\hline 4 & 0,829 & 0,2227 & Valid \\
\hline 5 & 0,743 & 0,2227 & Valid \\
\hline 6 & 0,761 & 0,2227 & Valid \\
\hline 7 & 0,724 & 0,2227 & Valid \\
\hline 8 & 0,644 & 0,2227 & Valid \\
\hline
\end{tabular}

Berdasarkan uji validitas instrumen dapat dilihat bahwa $r$ hitung untuk semua item motivasi lebih besar dari $r$ table $(0,2227)$. Dapat diambil keputusan bahwa amgket motivasi valid.

\section{Hasil Pengujian Validitas Instrumen Variabel Hasil Belajar (Y) SPSS}

\begin{tabular}{|c|c|c|c|}
\hline No item & r hitung & r table (5\% 76) & Keterangan \\
\hline 1 & 0,618 & 0,2227 & Valid \\
\hline 2 & 0,638 & 0,2227 & Valid \\
\hline 3 & 0,579 & 0,2227 & Valid \\
\hline 4 & 0,724 & 0,2227 & Valid \\
\hline 5 & 0,664 & 0,2227 & Valid \\
\hline 6 & 0,700 & 0,2227 & Valid \\
\hline 7 & 0,605 & 0,2227 & Valid \\
\hline 8 & 0,499 & 0,2227 & Valid \\
\hline
\end{tabular}

Berdasarkan uji validitas instrumen dapat dilihat bahwa $r$ hitung untuk semua item hasil belajar lebih besar dari $r$ table $(0,2227)$. Dapat diambil keputusan bahwa amgket hasil belajar valid.

\section{B. Uji Reliabilitas}

Pengujian reliabilitas dalam penelitian ini menggunakan teknis analisis pengukuran koefisien Alpha (scale). Uji signifikasi dilakuan pada taraf alpha $=0,05$. Instrumen dapat dikatakan reliabel jika nilai alpha lebih besar dari $r$ tabel $(0,227)$.

Uji Reliabilitas Variabel

\begin{tabular}{|c|c|c|}
\hline Variabel & Koefisien Alpha & Keputusan \\
\hline $\mathrm{X} 1$ & 0,829 & Reliabel \\
\hline $\mathrm{X} 2$ & 0,853 & Reliabel \\
\hline
\end{tabular}




\begin{tabular}{|c|c|c|}
\hline X3 & 0,862 & Reliabel \\
\hline Y & 0,774 & Reliabel \\
\hline
\end{tabular}

Berdasarkan nilai reliabilitas instrumen tersebut dapat disimpulkan bahwa semua angket dalam penelitian ini reliabel atau konsisten sehingga dapat digunakan sebagai instrumen penelitian.

\section{V.2. Pengujian Asumsi Klasik}

\section{A. Uji Normalitas}

Uji normalitas dilakukan untuk melihat apakah nilai risidual terdistribusi secara normal atau tidak. Model regresi yang baik adalah yang memiliki nilai residual yang brdistribusi normal. Uji normalitas Kolmogorov Smirnov merupakan bagian dari uji asumsi klasik. Dasar Pengambilan keputusan pada uji normalitas adalah jika nilai signifikasi $>0,05$, maka nilai residual berdistribusi normal dan jika nilai signifikasi $<0,05$, maka nilai residual tidak berdistribusi normal.

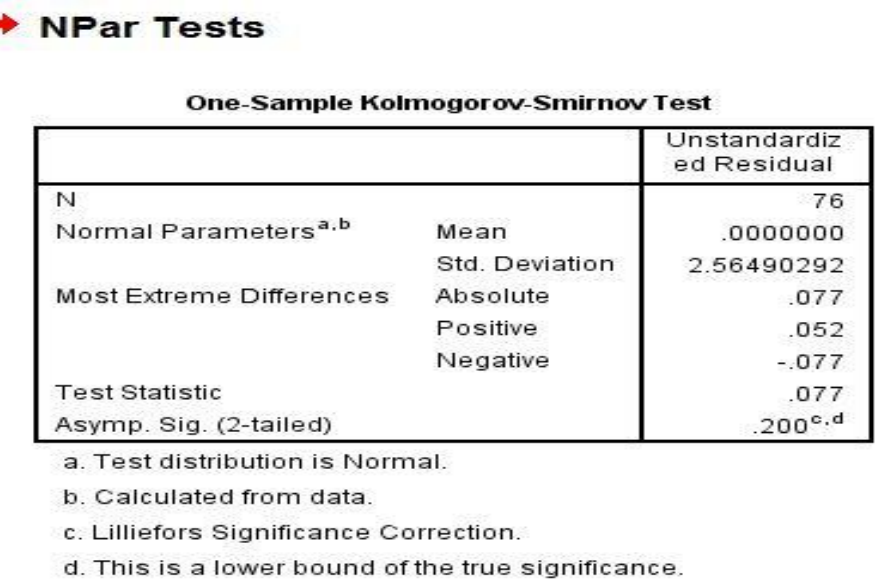

Berdasarkan hasil uji normalitas diketahui nilai signifikasi 0,200 > 0,05 maka dapat disimpulkan bahwa nilai residual berdistribusi normal sehingga dapat dilanjtkan ke analisis regresi.

\section{B. Uji Multikolinearitas}

Pengujian pada penelitian ini dilakukan dengan menggunakan metode Tolerance dan VIP (Variance Inflation Factor). Dasar pengambilan keputusan pada uji ini adalah :

- Melihat nilai Tolerance : Jika nolai Tolerance $>0,1$ maka artinya tidak terjadi Multikolonieritas.

- Melihat nilai VIF : Jika nilai VIF < 10 maka artinya tidak terjadi Multikolonieritas. 

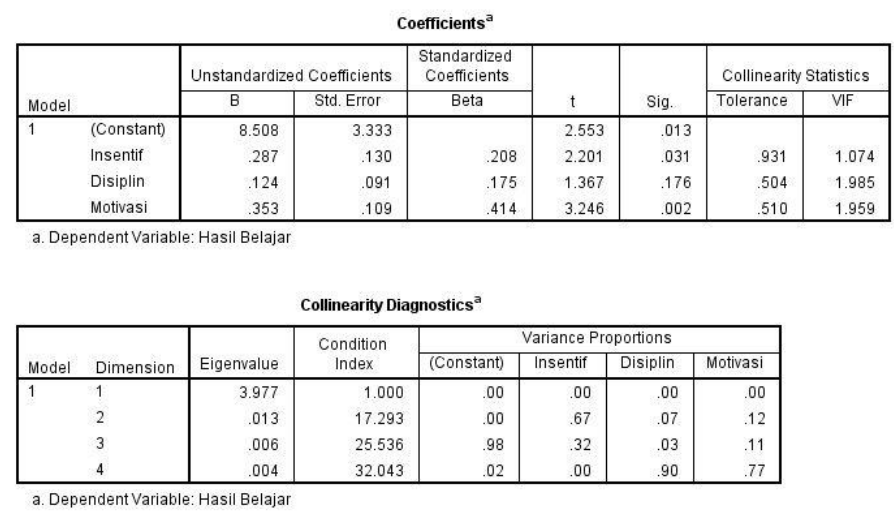

Dari tabel dapat dilihat bahwa :

1. Nilai Tolerance variabel insentif, disiplin dan motivasi lebih besar dari $>0,10$ maka artinya tidak terjadi multikolinearitas.

2. Nilai VIF variabel insentif, disiplin dan motivasi lebih kecil dari $<10.0$ artinya tidak terjadi multikolinearitas.

\section{Uji Heterokedastisitas}

Suatu model regresi yang mengandung heterokedastisitas akan menghasilkan parameter yang bias sehingga akan menyebabkan kesalahan dalam perlakuannya. Suatu model dapat dikatakan baik apabila didalamnya tidak diperoleh heterokedastisitas melainkan homokedastisitas.

Dasar pengambilan keputusan adalah :

- Jika nilai sig >0,05 maka tidak terjadi Heterokedastisitas

- Jika nilai sig $<0,05$ maka terjadi Heterokedastisitas

Coefficients $^{a}$

\begin{tabular}{|ll|r|r|r|r|r|}
\hline \multirow{2}{*}{ Model } & \multicolumn{2}{|c|}{ Unstandardized Coefficients } & \multicolumn{2}{c|}{$\begin{array}{c}\text { Standardized } \\
\text { Coefficients }\end{array}$} & \\
\cline { 3 - 4 } & \multicolumn{1}{|c|}{$\mathrm{B}$} & \multicolumn{1}{|c|}{ Std. Error } & \multicolumn{1}{c|}{ Beta } & \multicolumn{1}{c|}{ Sig. } \\
\hline 1 & (Constant) & 5.076 & 2.031 & & 2.499 & .015 \\
& Insentif & -.098 & .080 & -.146 & -1.227 & .224 \\
& Disiplin & -.078 & .055 & -.227 & -1.408 & .164 \\
& Motivasi & .062 & .066 & .149 & .929 & .356 \\
\hline
\end{tabular}

a. Dependent Variable: RES2

Dari hasil uji heterokedastisitas pada tabel diatas dapat dilihat bahwa nilai sig. variabel insentif, disiplin dan motivasi lebih besar > 0,05 yang menunjukkan bahwa tidak terjadi heterokedastisitas.

\section{V.3. Analisis Regresi Linier Berganda}

Analisis linier berganda bertujan untuk mengetahui ada atau tidaknya pengaruh variabel bebas $(\mathrm{X})$ terhadap variabel terikat $(\mathrm{Y})$.

\begin{tabular}{|c|c|c|c|c|c|c|}
\hline \multirow{2}{*}{\multicolumn{2}{|c|}{ Model }} & \multicolumn{2}{|c|}{ Unstandardized Coefficients } & \multirow{2}{*}{$\begin{array}{c}\begin{array}{c}\text { Standardized } \\
\text { Coefficients }\end{array} \\
\text { Beta }\end{array}$} & \multirow[b]{2}{*}{$t$} & \multirow[b]{2}{*}{ Sig. } \\
\hline & & $\mathrm{B}$ & Std. Error & & & \\
\hline \multirow[t]{4}{*}{1} & (Constant) & 8.508 & 3.333 & & 2.553 & .013 \\
\hline & Insentif $(X 1)$ & .287 & .130 & .208 & 2.201 & .031 \\
\hline & Disiplin (X2) & .124 & .091 & .175 & 1.367 & .176 \\
\hline & Motivasi $(\chi 3)$ & .353 & .109 & .414 & 3.246 & .002 \\
\hline
\end{tabular}

a. Dependent Variable: Hasil Belajar (n) 


Model Summary
\begin{tabular}{|l|l|r|r|r|}
\hline Model & R & R Square & $\begin{array}{c}\text { Adjusted R } \\
\text { Square }\end{array}$ & $\begin{array}{c}\text { Std. Error of } \\
\text { the Estimate }\end{array}$ \\
\hline 1 & $.635^{\text {a }}$ & .404 & .379 & 2.61779 \\
\hline
\end{tabular}

a. Predictors: (Constant), Motivasi $(X 3)$, Insentif $(X 1)$, Disiplin $(X 2)$

Berdasarkan tabel diatas, dapat diperoleh model regresi linier berganda sebagai berikut $\mathrm{Y}=8,508+0,287 \mathrm{X}_{1}+0,124 \mathrm{X}_{2}+\left(0,353 \mathrm{X}_{3}\right)+\mathrm{e}$

a. Nilai konstanta sebesar 8,508 menunjukkan bahwa apabila variabel independen konstan atau sama dengan nol maka kinerja karyawan akan naik sebesar 8,508.

b. Besarnya koefisian regresi $\beta_{1}$ adalah 0,287 , hal ini menunjukkan bahwa dengan meningkatnya variabel insentif maka akan menaikkan kinerja karyawan sebesar 0,287 .

c. Besarnya koefisian regresi $\beta_{2}$ adalah 0,124 , hal ini menunjukkan bahwa dengan meningkatnya variabel disiplin maka akan meningkatkan kinerja karyawan sebesar 0,124 .

d. Besarnya koefisian regresi $\beta_{3}$ adalah 0,353 , hal ini menunjukkan bahwa dengan meningkatnya variabel pengawasan maka akan menurunkan kinerja karyawan sebesar 0,353.

e. Besarnya nilai koefisien korelasi berganda (R) adalah 0,635, hal ini menunjukkan bahwa besarnya pengaruh variabel insentif, disiplin dan motivasi terhadap kinerja karyawan sebesar 0,635.

f. Besarnya nilai koefisien adjusted determinasi $\left(\mathrm{R}^{2}\right)$ adalah 0,379 hal ini menunjukkan bahwa besarnya pengaruh variabel variabel insentif, disiplin dan motivasi terhadap hasil belajar sebesar 0, 379 atau $(37,9 \%)$ dan sisanya sebesar 0,621 atau 62,1\% dipengaruhi oleh faktor atau variabel lain yang tidak dimasukkan dalam model penelitian.

\section{A. Uji F (Simultan)}

Uji $\mathrm{F}$ bertujuan untuk mengetahui ada atau tidaknya pengaruh simultan (bersama-sama) yang diberkan variabel bebas $(\mathrm{X})$ terhadap variabel terikat $(\mathrm{Y})$.

Perumusan Hipotesis :

$\mathrm{H} 0=$ Terdapat pengaruh insentif (X1), disiplin (X2) dan motivasi (X3) terhadap Hasil

Belajar (Y)

Dimana tingkat kepercayaan $95 \%$, alpha $=0,05$

Dasar pengambilan keputusan :

- Jika nilai sig <0,05 atau F hitung $>\mathrm{F}$ tabel maka terdapat pengaruh variabel $\mathrm{X}$ secara simultan terhadap variabel $Y$.

- Jika nilai sig > 0,05 atau $\mathrm{F}$ hitung $<\mathrm{F}$ tabel maka tidak terdapat pengaruh variabel $\mathrm{X}$ secara simultan terhadap variabel $\mathrm{Y}$.

$\mathrm{F}$ tabel $=\mathrm{F}(\mathrm{k}: \mathrm{n}-\mathrm{k})=\mathrm{F}(3: 76-3)=\mathrm{F}(3: 73)=2,730$

\begin{tabular}{|ll|r|r|r|r|l|}
\hline \multicolumn{1}{|c|}{ Model } & \multicolumn{1}{c|}{$\begin{array}{c}\text { Sum of } \\
\text { Squares }\end{array}$} & \multicolumn{1}{c|}{ df } & Mean Square & \multicolumn{1}{c|}{$\mathrm{F}$} & \multicolumn{1}{c|}{ Sig. } \\
\hline 1 & Regression & 333.793 & 3 & 111.264 & 16.236 & $.000^{\mathrm{b}}$ \\
& Residual & 493.405 & 72 & 6.853 & & \\
& Total & 827.197 & 75 & & & \\
\hline
\end{tabular}

a. Dependent Variable: Hasil Belajar $(n$

b. Predictors: (Constant), Motivasi $(X 3)$, Insentif $(X 1)$, Disiplin $(X 2)$ 
Berdasarkan output di atas diketahui nilai signifikansi untuk pengaruh X1, X2 dan X3 secara simultan terhadap $Y$ adalah sebesar $0,000<0,05$ dan nilai F hitung 16,236 > 2,730 sehingga dapat disimpulkan bahwa $\mathrm{H} 0$ diterima yang berarti terdapat pengaruh XI, X2 dan X3 secara simultan terhadap Y

\section{B. Uji t (Parsial)}

Uji t bertujuan untuk mengetahui ada atau tidaknya pengaruh parsial (sendiri) yang diberikan veriabel bebas $(\mathrm{X})$ terhadap variabel terikat $(\mathrm{Y})$.

Perumusan Hipotesis

- $\mathrm{H} 1=$ Terdapat pengaruh insentif (X1) terhadap Hasil Belajar (Y)

- $\quad \mathrm{H} 2=$ Terdapat pengaruh disiplin (X2) terhadap Hasil Belajar (Y)

- $\mathrm{H} 3$ = Terdapat pengaruh motivasi (X3) terhadap Hasil Belajar (Y)

Dimana tingkat kepercayaan $95 \%$, alpha $=0,05$

Dasar pengambilan keputusan :

- Jika nilai sig $<0,05$ atau $t$ hitung $>\mathrm{t}$ tabel maka terdapat pengaruh variabel $\mathrm{X}$ terhadap variabel Y.

- Jika nilai sig > 0,05 atau thitung $<\mathrm{t}$ tabel maka terdapat pengaruh variabel $\mathrm{X}$ terhadap variabel Y.

Dimana $\mathrm{t}$ tabel $\left.=\mathrm{t}(\alpha / 2 ; \mathrm{n}-\mathrm{k}-1)=\mathrm{t} \underset{\text { coefficients }^{\mathrm{a}}}{(0,05 / 2} ; 6-3-1\right)=(0,025,72)=1,996$

\begin{tabular}{|c|c|c|c|c|c|c|}
\hline \multirow[b]{2}{*}{ Model } & & \multicolumn{2}{|c|}{ Unstandardized Coefficients } & \multirow{2}{*}{$\begin{array}{c}\text { Standardized } \\
\text { Coefficients } \\
\text { Beta }\end{array}$} & \multirow[b]{2}{*}{$t$} & \multirow[b]{2}{*}{ Sig. } \\
\hline & & B & Std. Error & & & \\
\hline \multirow[t]{4}{*}{1} & (Constant) & 8.508 & 3.333 & & 2.553 & .013 \\
\hline & Insentif $\left(X_{1}\right)$ & .287 & .130 & .208 & 2.201 & .031 \\
\hline & Disiplin $(\times 2)$ & .124 & .091 & .175 & 1.367 & .176 \\
\hline & Motivasi $(\chi 3)$ & .353 & .109 & .414 & 3.246 & .002 \\
\hline
\end{tabular}

- Pengujian Hipotesis pertama (H1)

Diketahui nilai Sig. untuk pengaruh X1 terhadap Y adalah sebesar 0,031 $<0,05$ dan nilai t hitung 2,201 > 1, 996 sehingga dapat disimpulkan bahwa H1 diterima yang berarti terdapat pengaruh X1 taerhadap Y.

- $\quad$ Pengujian Hipotesis kedua (H2)

Diketahui nilai Sig. untuk pengaruh X2 terhadap Y adalah sebesar 0,176 > 0,05 dan nilai t hitung 1,367 < 1, 996 sehingga dapat disimpulkan bahwa $\mathrm{H} 2$ ditolak yang berarti tidak terdapat pengaruh X3 taerhadap Y.

- Pengujian Hipotesis ketiga (H3)

Diketahui nilai Sig. untuk pengaruh X3 terhadap Y adalah sebesar 0,02 $<0,05$ dan nilai t hitung 3,246>1,996 sehingga dapat disimpulkan bahwa $\mathrm{H} 3$ diterima yang berarti terdapat pengaruh X3 taerhadap Y.

\section{Pengujian Nilai Koefisien Regresi (B)}

Berdasarkan nilai koefisien regresi (ß) antara insentif, disiplin dan motivasi maka variabel yang mempunyai pengaruh dominan terhadap hasil belajar mahasiswa Politeknik Ganesha Medan adalah variabel motivasi $\left(\mathrm{X}_{3}\right)$ dimana nilai koefisien regresinya ( $(\mathrm{)})$ sebesar 0,414 . Hal ini dapat disimpulkan bahwa variabel motivasi merupakan variabel yang mempunyai pengaruh paling dominan terhadap hasil belajar mahasiswa Politeknik Ganesha Medan 


\section{KESIMPULAN}

Berdasarkan hasil analisis dan pembahasan penelitian maka dapat diambil kesimpulan sebagai berikut :

1. Secara simultan pemberian insentif, peningkatan disiplin dan pemberian motivasi berpengaruh signifikan terhadap hasil belajar mahasiswa Politeknik Ganesha Medan. Hal ini dapat dikatakan bahwa pemberian insentif, peningkatan disiplin, dan pemberian motivasi yang dijalankan dengan baik dapat meningkatkan hasil belajar mahasiswa Politeknik Ganesha Medan.

2. Secara parsial pemberian insentif dan pemberian motivasi berpengaruh positif dan signifikan terhadap hasil belajar mahasiswa Politeknik Ganesha Medan sedangkan peningkatan disiplin berpengaruh positif dan tidak signifikan terhadap hasil belajar mahasiswa Politeknik Ganesha Medan.

3. Besarnya nilai koefisien korelasi berganda (R) adalah 0,404 . Hal ini menunjukkan bahwa pengaruh variabel pemberian insentif, peningkatan disiplin dan pemberian motivasi terhadap hasil belajar mahasiswa tidak cukup kuat yaitu sebesar 0,404 (karena tidak mendekati angka 1)

4. Besarnya nilai koefisien adjusted determinasi $\left(\mathrm{R}^{2}\right)$ adalah 0,379 , hal ini menunjukkan bahwa besarnya pengaruh variabel pemberian insentif, peningkatan disiplin, pemberian motivasi terhadap hasil belajar adalah sebesar 0,379 atau $(37,9 \%)$ dan sisanya sebesar 0,621 atau $(62,1 \%)$ dipengaruhi oleh faktor atau variabel lain yang tidak diteliti dalam model penelitian ini.

\section{DAFTAR PUSTAKA}

A.M, S. (2016). Interaksi dan Motivasi Belajar Mengajar. Jakarta: Raja Grafindo Persada.

Gaol, J. L. (2014). A to Z Human Capital : Manajemen Sumber Daya Manusia. Jakarta: PT Grasindo.

Ghozali, I. (2012). Aplikasi Analisis Multivariate dan Program IBM SPSS 20. Semarang: UNDIP.

Ghozali, I. (2018). Aplikasi Analisis Multivariate dengan program IBM SPSS 25.

Semarang: Badan Penerbit Universitas Diponegoro.

Hariandja. (2012). Manajemen Sumber Daya Manusia. Jakarta: Gramedia Widiasarana.

Kingsley, H. (1999). The Nature and Conditions of Learning, NewJersey. -: Prentice Hall Ings Engliwood Clifts.

Mangkunegara, A. P. (2012). Manajemen Sumber Daya Manusia. Bandung: PT Remaja Rosdakarya.

Nadiroh, F., \& Wahjoedi. (2016). Pengaruh Pemanfaatan Bantuan Dana Pendidikan dan Motivasi Belajar Terhadap Hasil Belajar Mahasiswa S1 Pendidikan Ekonomi Angkatan 2012 Universitas Negeri Malang. Malang: JPE.

Ranupandojo, H., \& Husnan, S. (2000). Manajemen Personalia Edisi Keempat. Yogyakarta: BPFE UGM.

S.T, S., \& P, P. (2012). Pengaruh Disiplin Belajar dan Lingkungan Teman Sebaya Terhadap Prestasi Belajar Mahasiswa Program Studi Pendidikan Akuntansi Angkatan 2009 Fakultas Ekonomi Universitas Negeri Yogyakarta. Yogyakarta: Jurnal Pendidikan Akuntansi Indonesia.

Santoso, S. (2012). Panduan Lengkap SPSS Versi 20. Jakarta: PT Elex Media Komputindo.

Sitinjak, T., \& Sugiarto. (2006). LISREL. Yogyakarta: Graha Ilmu. 
Slameto. (n.d.). Belajar dan Faktor-faktor yang Mempengaruhinya. Jakarta: Rineka Cipta.

Sugiono. (2012). Statistika Untuk Penelitian. Bandung: Alfabeta.

Zuhro, C. (2016). Pengaruh Sikap, Motivasi dan Metode Mengajar Terhadap Hasil Belajar Mahasiswa pada MKDU Bahasa Inggris Di Politeknik Negeri Jember. Jember: Jurnal Ilmiah Inovasi. 